\title{
SEED DORMANCY REMOVAL TREATMENTS AND GERMINATION CHARACTERISTICS OF Acer trautvetteri Medvedev SEEDS
}

\author{
METODE SAVLADAVANJA DORMANTNOSTI I ZNAČAJKE \\ KLIJAVOSTI SJEMENA VRSTE Acer trautvetteri Medvedev
}

\author{
Hanife Erdoğan Genç ${ }^{1 *}$, Ali Ömer Üçler ${ }^{2}$
}

\begin{abstract}
SUMIMARY
In this study, seed dormancy removal and germination characteristics of Acer trautvetteri Medvedev, is one of the major maple species of the eastern Black Sea region, were studied. To do that, the seeds were collected in 2008 three times with aproximately 15-days intervals. In order to remove dormancy, several germination treatments were applied. The treatments were (1) different seed collection time, (2) soaking in water, (3) cold-moist stratification and (4) $\mathrm{GA}_{3}$ (gibberellic acid) application. The treated seeds were germinated in growing chamber at $5{ }^{\circ} \mathrm{C}$ and in greenhouse conditions. This research indicated that seeds of Acer trautvetteri exhibit physiological dormancy and require stratification period to remove seed dormancy. The highest germination percentage in the growing chamber subjected to $\mathrm{GA}_{3}$ application after eight weeks of stratification treatment was $66 \%$ for Acer trautvetteri seeds. The highest germination percentage in greenhouse was obtained with cold stratification after eight weeks (81 \%). Although $\mathrm{GA}_{3}$ treatment had a positive effect on germination in growth chamber $+5^{\circ} \mathrm{C}, \mathrm{GA}_{3}$ treatment had a negative effect on germination in greenhouse conditions. Soaking in water of nonstratified seeds wasn't any significant difference on seed germination. There was a positive correlation between seed collection time and germination $(\mathrm{r}=0.59)$. As a result, the third collection time (in october) should be preferred as seed collection time in Acer trautvetteri seeds, considering that it may vary according to the climatic conditions of the year.
\end{abstract}

KEY WORDS: Acer trautvetteri; seed; dormancy; stratification; gibberellic acid

\section{INTRODUCTION}

\section{UVOD}

Acer trautvetteri Medvedev has a geographic distribution in Caucasia and Turkey. It ranges between $400 \mathrm{~m}$ and $2100 \mathrm{~m}$. It is especially common in North Eastern Anatolia and is also common in the region of Kırklareli, Balıkesir, İstanbul, Kocaeli, Bolu, Sinop, Ordu, Giresun, Trabzon, Rize and Artvin in Turkey (Ansin and Ozkan 1997; Davis 1969). Maple are well known for their autumnal colour (Kumar et al. 2017). Also, many of the maples have ornamental value be- cause of their attractive foliage, interesting crown shape, flowers and fruit (Ansin and Ozkan 1997; Zasada and Strong 2008; Ognjenović et al. 2018). Maple wood has a light color and is used in veneer and furniture manufacturing (Ulker and Hiziroglu 2018). Acer trautvetteri grows fast and has a economic value for the forest industry (Korkut and Büyüksari 2006). Furthermore, Acer trautvetteri wood could be used by applying proper heat treatment methods in some areas such as windows frame (Korkut and Guller 2008). Acer seeds are acccepted by several researchers in the class of seeds with seed dormancy (Bradbeer 1988; Peroni 1995; 
Derkx 2000; Piotto and Noi 2003; Gleiser et al. 2004; Zasada and Strong 2008). Also, several studies have shown that Acer seeds have dormant embryo (Webb and Wareing 1972; Pinfield et al. 1987; Pinfield and Stutchbury 1990; Marković et al. 2019). Acer species seeds have different pre-germination requirements according to seed ripening time and the nature of dormancy (Phartyal et al. 2002). In Maple species, an endogenous dormancy is generally seen due to requiring a rest period after maturation of the embryo (Ucler and Turna 2005). There are different tecniques for the removal of dormancy in Acer seeds depending on the types of dormancy. Dormancy was removed by cold-moist stratification in many Acer species (Farmer and Cunningham 1981; Tylkowski 1995; Tremblay et al. 1996; Savage et al. 1998; Bourgoin and Simpson 2004; Gultekin 2007; Farhadi et al. 2013; Erdogan Genc and Ucler 2020). In addition to cold-moist stratification, gibberellic acid also promotes breaking seed dormancy and stimulates seed germination in many species (Chen and Chang 1972; Beyhan et al. 1999; Phartyal et al. 2003; Drăghici and Abrudan 2010; Stejskalová et al. 2015; Kumar et all. 2017 ). Although Acer trautvetteri spreads naturally in the Eastern Black sea forests, it can not be produced sufficiently in both private and forest nurseries. The use of naturally spreading species in reforestation studies is one of the main principles. In this study, seed dormancy removal of Acer trautvetteri, one of the important Acer species of the eastern Black Sea region, were studied. The aim of the present study was to investigate the effect of different seed collection time, cold-moist stratification, $\mathrm{GA}_{3}$ and soaking applications on seed dormancy removal and germination in Acer trautvetteri seeds.

\section{MATERIALS AND METHODS MATERIJALI I METODE}

\section{Seed material - Sjemenski materijal}

The seeds were collected from district of Şalpazarı, Geyikli village ( 800m, $532050 \mathrm{~N}, 4516450 \mathrm{E}$ ) in Trabzon, Turkey at three different times with 15-day intervals (on September 12, 2008; on September 27, 2008; on October 10, 2008). The beginning of the greyish brown colour of the seed was decided as first collection time (Chauhan and Arun 1998). The seeds were harvested at three times with aproximately 15 -days intervals. Seed collected trees were marked with red oil paint. Thus, the same trees were used for different seed collection times. The harvested seeds were labeled and put into black plastic bags. The seeds were dewinged by hand and air-dried in the laboratory. The seeds were placed in glass jars after they reached approximately dry air humidity $(10 \pm 2 \%)$ and stored in a cooler $\left(+4{ }^{\circ} \mathrm{C}\right)$. The initial moisture content, the 1000 -seed weight and seed viability according to Tetrazolium test of Acer trautvetteri seeds were determined for each collection time. The initial moisture content was determined by using drying oven method at $104 \pm 1{ }^{\circ} \mathrm{C} 17$ hour (ISTA, 1996).

Table 1. Laboratory and Greenhouse Experiments

Tablica 1. Tretmani u laboratoriju i u stakleniku

\begin{tabular}{|c|c|c|}
\hline $\begin{array}{l}\text { Treatments } \\
\text { Tretmani }\end{array}$ & $\begin{array}{l}\text { Laboratory experiments } \\
\text { Laboratorijski pokus }\end{array}$ & $\begin{array}{l}\text { Greenhouse experiments } \\
\text { Staklenički pokus }\end{array}$ \\
\hline 1 & $\begin{array}{l}\text { No soaking and direct germination treatment } \\
\text { Bez močenja i sjetva odmah nakon sakupljanja }\end{array}$ & $\begin{array}{l}\text { No soaking and direct sowing treatment } \\
\text { Bez močenja i sjetva odmah nakon sakupljanja }\end{array}$ \\
\hline 2 & $\begin{array}{l}48 \mathrm{hr} \text { soaking and germination treatment } \\
48 \text {-satni postupak močenja ispitivanje kllijavosti }\end{array}$ & $\begin{array}{l}48 \mathrm{hr} \text { soaking and sowing } \\
48 \text { sati močenja i sjetva }\end{array}$ \\
\hline 3 & $\begin{array}{l}8 \text { week (w) stratification (st.) and germination treatment } \\
8 \text { tjedana (t) stratifikacija (st.) i ispitivanje klijavosti }\end{array}$ & $\begin{array}{l}\text { No soaking }+8 \text { w stratification } \\
\text { Bez močenja }+8 \text { t stratifikacije }\end{array}$ \\
\hline 4 & $\begin{array}{l}\text { No soaking }+50 \mathrm{ppm} \mathrm{GA}_{3} \\
\text { Bez močenja }+50 \mathrm{ppm} \mathrm{GA} A_{3}\end{array}$ & $\begin{array}{l}48 \text { hr soaking }+8 \text { w stratification } \\
48 \text { sati močenja }+8 \text { t stratifikacije }\end{array}$ \\
\hline 5 & $\begin{array}{l}48 \mathrm{hr} \text { soaking }+50 \mathrm{ppm} \mathrm{GA} \mathrm{A}_{3} \\
48 \text { sati močenja }+50 \mathrm{ppm} \mathrm{GA}_{3}\end{array}$ & 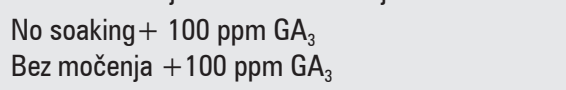 \\
\hline 6 & $\begin{array}{l}8 \text { w stratification (st.) }+50 \text { ppm GA } \\
8 \text { t stratifikacije (st.) }+50 \text { ppm GA }\end{array}$ & $\begin{array}{l}48 \text { h soaking }+100 p p m \mathrm{GA}_{3} \\
48 \text { sati močenja }+100 p p m \mathrm{GA}_{3}\end{array}$ \\
\hline 7 & $\begin{array}{l}\text { No soaking }+100 \text { ppm GA } \\
\text { Bez močenja }+100 \text { ppm GA }\end{array}$ & $\begin{array}{l}\text { No soaking }+8 \text { w stratification }+100 p p m \mathrm{GA}_{3} \\
\text { Bez močenja }+8 \text { t stratifikacije }+100 p p m \mathrm{GA}_{3}\end{array}$ \\
\hline 8 & $\begin{array}{l}48 \mathrm{hr} \text { soaking }+100 \mathrm{ppm} \mathrm{GA} \\
48 \text { sati močenja }+100 \mathrm{ppm} \mathrm{GA}\end{array}$ & $\begin{array}{l}48 \mathrm{hr} \text { soaking }+8 \text { w stratification }+100 \mathrm{ppm} \mathrm{GA}_{3} \\
48 \text { sati močenja }+8 \text { t stratifikacije }+100 \mathrm{ppm} \mathrm{GA}_{3}\end{array}$ \\
\hline 9 & $\begin{array}{l}8 \text { w stratification }+100 \mathrm{ppm} \mathrm{GA}_{3} \\
8 \mathrm{t} \text { stratifikacije }+100 \mathrm{ppm} \mathrm{GA}{ }_{3}\end{array}$ & $\begin{array}{l}\text { No soaking }+400 p p m \mathrm{GA}_{3} \\
\text { Bez močenja }+400 \mathrm{ppm} \mathrm{GA} \mathrm{GA}_{3}\end{array}$ \\
\hline 10 & $\begin{array}{l}\text { No soaking }+400 \mathrm{ppm} \mathrm{GA} \\
\text { Bez močenja }+400 \mathrm{ppm} \mathrm{GA}\end{array}$ & $\begin{array}{l}48 \mathrm{hr} \text { soaking }+400 \mathrm{ppm} \mathrm{GA} \\
48 \text { sati močenja }+400 \mathrm{ppm} \mathrm{GA} \\
3\end{array}$ \\
\hline 11 & $\begin{array}{l}48 \mathrm{hr} \text { soaking }+400 \mathrm{ppm} \mathrm{GA} \\
48 \text { sati močenja }+400 \mathrm{ppm} \mathrm{GA} \mathrm{GA}_{3}\end{array}$ & $\begin{array}{l}\text { No soaking }+8 \text { w stratification }+400 p p m \mathrm{GA}_{3} \\
\text { Bez močenja }+8 \text { t stratifikacije }+400 \mathrm{ppm} \mathrm{GA}\end{array}$ \\
\hline 12 & $\begin{array}{l}8 \text { w stratification }+400 \mathrm{ppm} \mathrm{GA}_{3} \\
8 \text { t stratifikacije }+400 \mathrm{ppm} \mathrm{GA}{ }_{3}\end{array}$ & $\begin{array}{l}48 \mathrm{hr} \text { soaking }+8 \mathrm{w} \text { stratification }+400 \mathrm{ppm} \mathrm{GA} \mathrm{A}_{3} \\
48 \text { sati močenja }+8 \text { t stratifikacije }+400 \mathrm{ppm} \mathrm{GA}\end{array}$ \\
\hline
\end{tabular}




\section{Laboratory and Greenhouse experiments - Tretmani u laboratoriju i u stakleniku}

In this study, treatments of growth chamber and greenhouse are shown in Table 1.

\section{Laboratory Experiments - Istraživanje u laboratoriju}

The seeds were soaked for 48 hour in water at room temperature $\left(22^{\circ} \mathrm{C} \pm 2^{\circ} \mathrm{C}\right)$ (Genc 2012) before germination and sowing treatments in order to break dormancy caused by seed coat. Also, the seeds were treated with cold-moist stratification treatment to break seed dormancy. The seeds were mixed with approximately $\% 40$ humidified sand and placed in plastic bags, and then stored in the refrigerator (at $4^{\circ} \mathrm{C}$ ) for cold-moist stratification treatment (Saatcioglu 1971; Yahyaoglu and Olmez 2005). In pre-experiments, the highest germination percentage of stratified seeds was obtained in seeds treated with stratification for 8 weeks. Therefore, stratification period was determined as 8 weeks in this study. As a different treatment, the seeds collected different collection time were treated with $\mathrm{GA}_{3}$ (Giberellic acid; $50,100,400 \mathrm{ppm}$ ) for 24 hours and germinated in growth chamber (Table 1). Germination tests were conducted in petri dishes (ISTA 1996) and 100 (4 X 25) seeds were used for each germination test. Petri dishes and filter paper were sterilized in the oven at $160^{\circ} \mathrm{C}$ for approximately 2 hours. Petri dishes covered and randomly placed in growth chamber. The seeds with radicles longer than $3 \mathrm{~mm}$ were tought to be germinated and taken from the petri dishes (Jensen 2001). Germination tests were considered completed when there was no germination for 14 consecutive days (Tremblay et al. 1996). In pre-experiments, the highest germination percentage of Acer trautvetteri seeds was observed in germination experiments at $+5^{\circ} \mathrm{C}$. Therefore, in this study, the germination experiments were carried out at $+5^{\circ} \mathrm{C}$.

\section{Greenhouse Experiments - Istraživanja u stakleniku}

In order to evaluate the germination performance of Acer trautvetteri seeds in the greenhouse conditions, seed beds (soil ) were used in the greenhouse at East Black Sea Forestry Research Institue. The seeds were subjected to soaking 48 hours water, 8 week stratification, soaking 48 hours water +8 week stratification and $\mathrm{GA}_{3}$ applications $(100$ and $400 \mathrm{ppm}$ ) (Table 1).100 seeds were used for each treatment. The seeds were sown on seed bed by using line sowing method (Genc 2012). 50 seeds were sown in each line and sandforest soil mixture was used as cover material. The irrigation in greenhouse was done by automatically. The temperature of morning, noon and evening in the greenhouse was measured by thermometer and recorded regularly from the beginning of germination to the end of germination. Germinants were recorded weekly.

\section{Statistical Analysis - Statistička analiza}

In the present study, data were analyzed using the SPSS statistical software. Correlation analysis, Analysis of variance (ANOVA), Duncan's test and Independent samples t-test were used (Ozdamar 2010).

\section{RESULTS}

\section{REZULTATI}

\section{Laboratory Experiments - Istraživanja u laboratoriju}

The seeds collected at three different times were germinated in the growing chamber at $+5{ }^{\circ} \mathrm{C}$ after they had been subjected to soaking 48 hours water, 8 week stratification and $\mathrm{GA}_{3}$ applications (50, 100 and $400 \mathrm{ppm}$ ). The difference between the treatments was tested by analyses of variance and the significance of differences between groups was tested by Duncan's test (Table 2 and Table 3)

Tablo 2. Results of ANOVA for effects of different pretreatments on seed germination

Tablica 2. Rezultati ANOVA za utjecan različitih načina predsjetvene pripreme na klijavost sjemena

\begin{tabular}{|c|c|c|c|c|c|}
\hline $\begin{array}{l}\text { Variable Source } \\
\text { Izvor varijabolnosti }\end{array}$ & $\begin{array}{l}\text { Sum of Squares } \\
\text { Suma kvadrata }\end{array}$ & $\begin{array}{l}\text { Degree of freedom } \\
\text { Stupnjevi slobode }\end{array}$ & $\begin{array}{l}\text { Mean square } \\
\text { Srednji kvadrat }\end{array}$ & $\begin{array}{c}\text { F-value } \\
\text { F - vrijednost }\end{array}$ & $\begin{array}{c}\boldsymbol{P} \text { - value } \\
\boldsymbol{P} \text { - vrijednost }\end{array}$ \\
\hline $\begin{array}{l}\text { Collection time } \\
\text { Vrijeme sakupljanja }\end{array}$ & 308,22 & 2 & 154,11 & 0,5 & 0,60 \\
\hline $\begin{array}{l}\text { Stratification } \\
\text { Stratifikacija }\end{array}$ & 11160,22 & 2 & 5580,11 & 18,32 & $0,00^{*}$ \\
\hline $\begin{array}{l}\mathrm{GA}_{3} \text { application } \\
\text { Primjena } \mathrm{GA}_{3}\end{array}$ & 8868,00 & 3 & 2956,00 & 9,70 & $0,00^{*}$ \\
\hline $\begin{array}{l}\text { Collection time } \times \text { Stratification } \\
\text { Vrijeme sakupljanja } \times \text { Stratifikacija }\end{array}$ & 2944,44 & 4 & 736,11 & 2,41 & 0,05 \\
\hline $\begin{array}{l}\text { Collection time } \times \mathrm{GA}_{3} \text { application } \\
\text { Vrijeme sakupljanja } \times \text { primjena } \mathrm{GA}_{3}\end{array}$ & 714,00 & 6 & 119,00 & 0,39 & 0,88 \\
\hline $\begin{array}{l}\text { Stratification } \times \mathrm{GA}_{3} \text { application } \\
\text { Stratifikacija } \times \text { primjena } \mathrm{GA}_{3}\end{array}$ & 1459,33 & 6 & 243,22 & 0,79 & 0,57 \\
\hline $\begin{array}{l}\text { Collection time } \times \text { Stratification } \times \mathrm{GA}_{3} \text { application } \\
\text { Vrijeme sakupljanja } \mathrm{x} \text { stratifikacija } \mathrm{x} \text { primjena } \mathrm{GA}_{3}\end{array}$ & 1062,66 & 12 & 88,55 & 0,29 & 0,99 \\
\hline
\end{tabular}

${ }^{*} p<0,05$ (There is a statistically difference)

${ }^{*} \mathrm{p}<0,05$ (Postoji statistička razlika) 
Tablo 3. Germination percentages and Duncan's test groups Tablica 3. Klijavost sjemena i grupe Dunkanovog testa

\begin{tabular}{|c|c|c|c|}
\hline $\begin{array}{l}\text { Variable Source } \\
\text { Izvor varijabilnosti }\end{array}$ & $\begin{array}{l}\text { Treatments } \\
\text { Tretmani }\end{array}$ & $\mathrm{N}$ & $\begin{array}{c}\text { Mean value } \pm \text { St. Deviation } \\
\text { Srednja vrijednost } \pm \text { st. Devijacija }\end{array}$ \\
\hline \multirow{3}{*}{$\begin{array}{l}\text { Collection time } \\
\text { Vrijeme sakupljanja }\end{array}$} & $\begin{array}{c}\text { September } 12 \\
\text { 12.rujna }\end{array}$ & 48 & $42,25 \pm 24,36 \mathbf{a}$ \\
\hline & $\begin{array}{c}\text { September } 27 \\
\text { 27.rujna }\end{array}$ & 48 & $39,83 \pm 20,49 a$ \\
\hline & $\begin{array}{l}\text { October } 10 \\
\text { 10.listopada }\end{array}$ & 48 & $38,75 \pm 15,61 \mathbf{a}$ \\
\hline \multirow{3}{*}{$\begin{array}{l}\text { Stratification* } \\
{ }^{*} \text { Stratifikacija }\end{array}$} & $\begin{array}{c}8 \text { week stratification } \\
8 \text { tjedana stratifikacije }\end{array}$ & 48 & $52,25 \pm 20,61 a$ \\
\hline & $\begin{array}{l}\text { No stratification } \\
\text { Bez stratifikacije }\end{array}$ & 48 & $37,25 \pm 19,24 \mathbf{b}$ \\
\hline & $\begin{array}{l}48 \text { hour soaking water + no stratification } \\
48 \text { sati močenja }+ \text { Bez stratifikacije }\end{array}$ & 48 & $31,33 \pm 15,19 \mathbf{b}$ \\
\hline \multirow{4}{*}{$\begin{array}{l}\mathrm{GA}_{3} \text { application } \\
\text { Primjena } \mathrm{GA}_{3}\end{array}$} & $\mathrm{GA}_{3}$ 1:No GA & 36 & $27,44 \pm 15,91$ a \\
\hline & $\mathrm{GA}_{3} 2: 50 \mathrm{ppm} \mathrm{GA}{ }_{3}$ & 36 & $40,44 \pm 19,23 \mathbf{b}$ \\
\hline & $\mathrm{GA}_{3} 3: 100 \mathrm{ppm} \mathrm{GA}_{3}$ & 36 & $45,78 \pm 19,60 \mathbf{b}$ \\
\hline & $\mathrm{GA}_{3}$ 4: 400ppm GA & 36 & $47,44 \pm 20,88$ b \\
\hline
\end{tabular}

*Pretreatments of stratification and soaking + no startification were evaluated under this variable name

*Predtretmani stratifikacije i močenja + bez stratifikacije procijenjeni su pod ovim varijabilnim imenom

There was no effect of seed collection time on germination. Stratification treatment had a significant effect on germination $(p<0,05)$. There were no significant interactions between treatments (Table 2). The highest germination percentage was recorded after 8 weeks of cold-moist stratification (52,25\%). This result showed that 8 weeks coldmoist stratification significantly increased germination. Soaking in water of nonstratified seeds wasn't any significant difference on seed germination (Table 3). GA 3 treatment had a significant effect on germination (Table 2) but there wasn't any difference between $\mathrm{GA}_{3}$ doses (Table 3). Germination percentages were also evaluated in terms of treatments (Figure 1).

The highest germination percentage in the growing chamber was obtained in seeds collected at first seed collection time and subjected to $400 \mathrm{ppm} \mathrm{GA}_{3}$ application after eight weeks of stratification (66\%). Germination percentage was lower in control seeds. The soaking seeds in water for 48 hour wasn't any significant effect on germination (Figure 1).

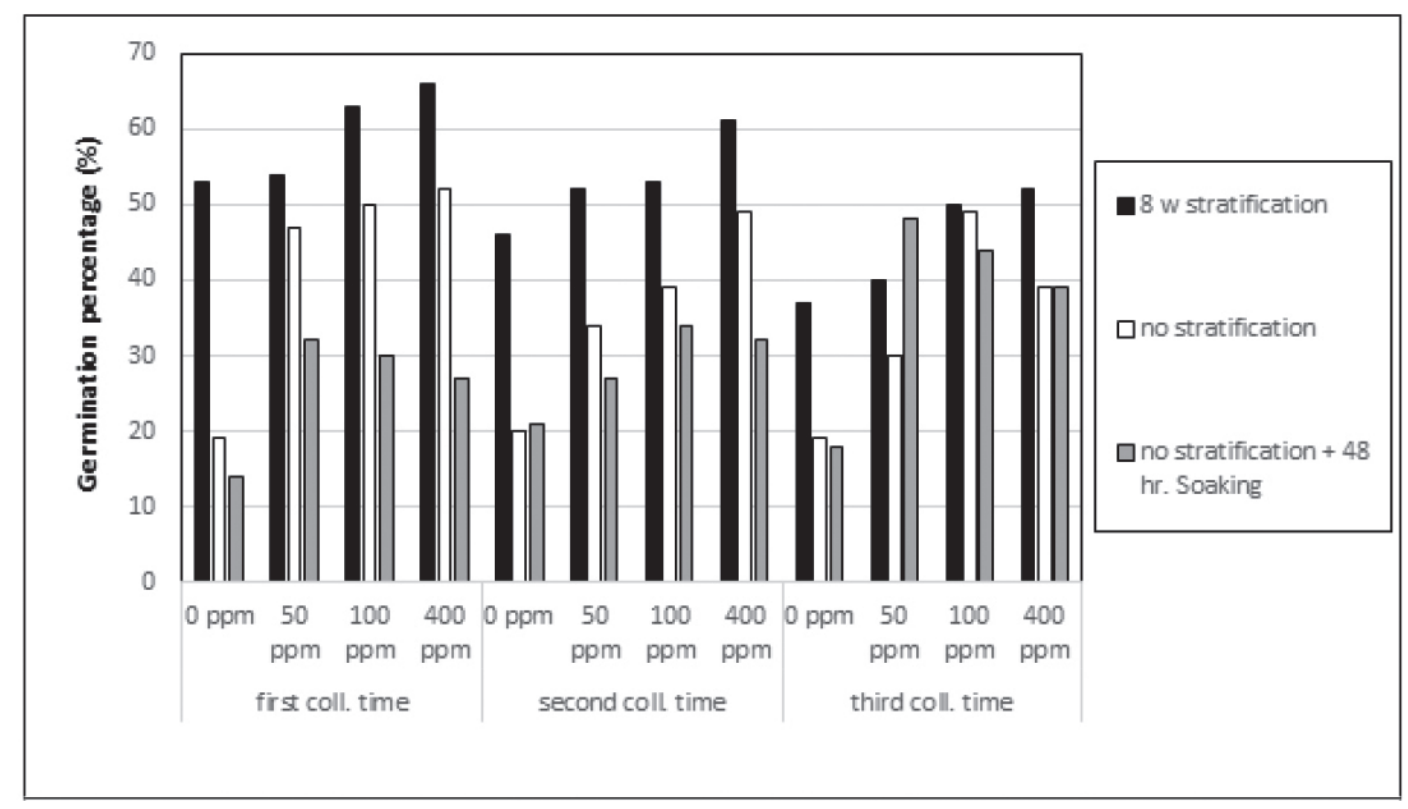

Figure 1. The effect of seed collection time, soaking in water, stratification and $\mathrm{GA}_{3}$ treatments on germination Slika 1. Utjecaj vremena prikuplnajna i močenja u vodi, stratifikacije i primjene $\mathrm{GA}_{3}$ na klijavost sjemena 
Tablo 4.Results of ANOVA for effects of different pretreatments in the greenhouse Tablica 4. Rezultati ANOVA za učinke različitih predtretmana u stakleniku

\begin{tabular}{|c|c|c|c|c|c|}
\hline $\begin{array}{l}\text { Variable Source } \\
\text { Izvor varijabolnosti }\end{array}$ & $\begin{array}{l}\text { Sum of Squares } \\
\text { Suma kvadrata }\end{array}$ & $\begin{array}{l}\text { Degree of freedom } \\
\text { Stupnjevi slobode }\end{array}$ & $\begin{array}{l}\text { Mean square } \\
\text { Srednji kvadrat }\end{array}$ & $\begin{array}{c}\text { F-value } \\
\text { F - vrijednost }\end{array}$ & $\begin{array}{c}\text { P-value } \\
P \text { - vrijednost }\end{array}$ \\
\hline $\begin{array}{l}\text { Collection time } \\
\text { Vrijeme sakupljanja }\end{array}$ & 492,11 & 2 & 246,05 & 1,51 & 0,23 \\
\hline $\begin{array}{l}\text { Stratification } \\
\text { Stratifikacija }\end{array}$ & 3960,50 & 1 & 3960,50 & 24,32 & 0,00 \\
\hline $\begin{array}{l}\mathrm{GA}_{3} \text { application } \\
\text { Primjena } \mathrm{GA}_{3}\end{array}$ & 2419,44 & 2 & 1209,72 & 7,43 & 0,00 \\
\hline $\begin{array}{l}\text { Collection time } \times \text { Stratification } \\
\text { Vrijeme sakupljanja } \times \text { Stratifikacija }\end{array}$ & 1027,00 & 2 & 513,50 & 3,15 & 0,05 \\
\hline $\begin{array}{l}\text { Collection time } \times \mathrm{GA}_{3} \text { application } \\
\text { Vrijeme sakupljanja } \times \text { primjena } \mathrm{GA}_{3}\end{array}$ & 1011,55 & 4 & 252,88 & 1,55 & 0,20 \\
\hline $\begin{array}{l}\text { Stratification } \times \mathrm{GA}_{3} \text { application } \\
\text { Stratifikacija } \times \text { primjena } \mathrm{GA}_{3}\end{array}$ & 577,00 & 2 & 288,50 & 1,77 & 0,18 \\
\hline $\begin{array}{l}\text { Collection time } \times \text { Stratification } \times \mathrm{GA}_{3} \text { application } \\
\text { Vr. prik. Sjemena } \times \text { Stratifikacija } \times \text { primjena } \mathrm{GA}_{3}\end{array}$ & 700,00 & 4 & 175,00 & 1,07 & 0,37 \\
\hline
\end{tabular}

Tablo 5.Germination percentages and Duncan's test groups of Acer trautvetteri seeds

Tablica 5. Postotak klijavosti sjemena vrste Acer trautvetteri i grupe Duncanovog testa

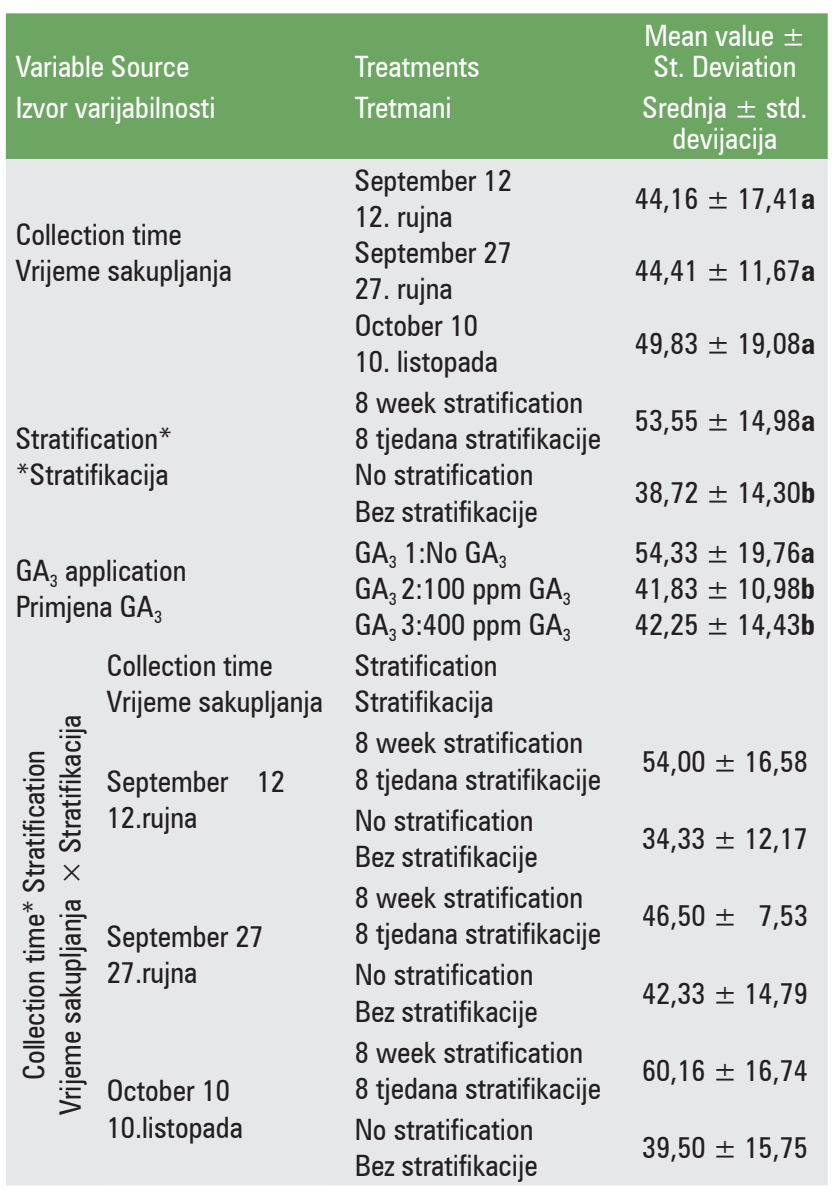

*The comparison of two independent populations was done by t test to evaluate the effect of stratification $(P=0,000)$

*Usporedba dviju neovisnih populacija napravljena je pomoću t testa kako bi se procijenili učinci stratifikacije $(P=0,000)$

\section{Greenhouse Experiments - Istraživanja u stakleniku}

The seeds collected at three different times were sown (15.01.2009) in the greenhouse after they had been subjected to soaking in water for 48 hours, stratification for 8 week and $\mathrm{GA}_{3}$ treatments (100 and $400 \mathrm{ppm}$ ). The air temperature in the greenhouse was at $+4^{\circ} \mathrm{C}$ in the morning, $+7^{\circ} \mathrm{C}$ at noon and $+9^{\circ} \mathrm{C}$ in the evening at the begining of first germination (26.01.2009). The average temperature in the greenhouse was at $+11^{\circ} \mathrm{C}$ in the morning, at $+15^{\circ} \mathrm{C}$ at noon and at $+19^{\circ} \mathrm{C}$ in the evening until the last date of germination. Germinants were counted at weekly. The difference between the treatments was tested by analyses of variance and the significance of differences between groups was tested by Duncan's test (Table 4 and Table 5).

There was no effect of seed collection time on germination in the greenhouse. The effect of stratification was significant on germination $(\mathrm{p}<0.05)$ (Table 4$)$. While the avarage germination percentage of seeds sown after eight weeks of stratification period was $53,55 \%$, the germination percentage of seeds sown unstratified was $38,72 \%$ (Table 5).GA treatment had a significant effect on germination but this effect was negative. There was a significant interaction between seed collection time and stratification (Table 4). The highest germination was obtained in seeds collected at third collection time (october 10) and sown after 8 week cold stratification (60,16\%). Also, according to the results of the correlation analysis, there was a positive correlation between seed collection time and germination $(r=0.59)$. Germination percentages were also evaluated in terms of treatments (Figure 2).

The highest germination percentage in the greenhouse was observed in seeds collected at third seed collection 


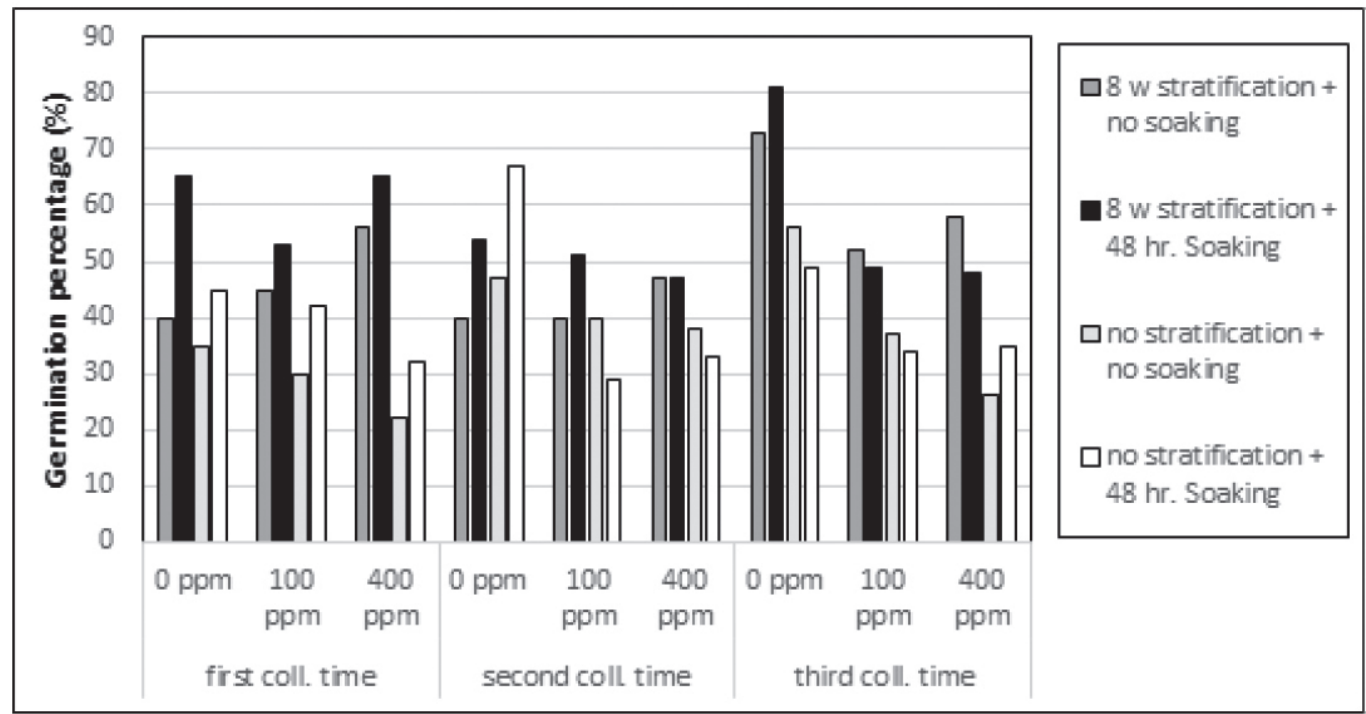

Figure 2. The effect of different pretreatments on germination of Acer trautvetteri seeds in green house Slika 2. Učinci različitih predtretmana na klijavost sjemena vrste Acer trautvetteri u stakleniku

time and subjected to eight weeks of stratification period after soaking in water for 48 hour without $\mathrm{GA}_{3}$ treatment (81\%).

\section{DISCUSSIONS RASPRAVA}

The germination percentage of Acer trautvetteri seeds stratified for eight weeks was higher than seeds unstratified in both the growing chamber and the greenhouse conditions. This fact confirms that seeds of Acer trautvetteri exhibit physiological dormancy and require stratification period to remove seed dormancy. Similarly, Yllmaz (2007) and Varbeva and Iliev (2015) reported that Acer trautvetteri seeds exhibit physiological dormancy. Several researches have already investigated that some maples had seed dormancy and mature Acer seeds require at least eight weeks of cold moist stratification to overcome dormancy (Urgenc 1998; Piotto and Noi 2003; Nasari et al. 2018; Erdogan Genc and Ucler 2020 ). Also, Kumar et al.(2017) obtained highest percentage of germination in Acer acuminatum after cold moist stratification for a period of 60 day. Whereas, Yilmaz (2007) reported that the dormancy of Acer trautvetteri seeds was completely removed by three months of chilling but all seed germinated during the chilling period. In the present study, cold-moist stratification period was determined as eight weeks for Acer trautvetteri seeds in the preliminary trials. When the stratification period was prolonged, most of the seeds germinated during stratification period. This situation was also detected in Acer cappadocicum seeds (Erdogan Genc and Ucler 2020). Yahyaoglu et al. (2006) reported that seed germination during stratification period was an important factor in obtaining low germination in sowing. Because of this reason, stratification process should be continued to species requiring stratification period before germination process until the first germinant appear in stratification medium. Because, the germination of the seeds in stratification medium negatively affected seed germination percentage. Urgenc (1998) also reported that stratification period could extend from one week to 3-4 weeks or even longer depending on the species. If startification period extend, the seeds could begin to germinate during stratification medium. This situation was also detected in some Maple species (Urgenc 1998; Piotto and Noi 2003; Varbeva and Iliev 2015). Therefore, in the present study, stratification period was suggested as eight weeks because of this sitution can be cause failure in sown. However, it is also stated that stratification period should be longer in order to break dormancy in seeds of Acer saccharum (Evans and Blazich 1999), five different Acer species (Yang and Lin 1999), Acer ceasium (Phartyal et al. 2003). Also, Farhadi et al. (2013) pointed out that the highest germination value of Acer velutinum seeds was obtained after 16 weeks of coldmoist stratification. In this study, it was determined that soaking unstratified seeds in water for 48 hours before germination trial was no statistically significant effect on germination in growth chamber conditions (Table 2). When treatments evaluated on the basis of indivudual, the highest germination percentage in the greenhouse was obtained from seeds collected at third seed collection time and subjected to eight weeks of stratification period after soaking in water for 48 hours without $\mathrm{GA}_{3}$ treatment ( $81 \%$ ) (Figure 2). Smilarly, Bourgoin and Simpson (2004) reported that the highest germination value of Acer pensylvanicum seeds was obtained from seeds subjected to the moist chilling for 16 weeks after soaking 48 hours ( $92 \%$ ). Furthermore, it was observed that soaking different Acer seeeds in water for 48 $\mathrm{hr}$ before germination trials increased germination rate 
(Webb and Dumbroff 1969; Webb 1974 ). According to analysis of variance (Table 2), it was found out that $\mathrm{GA}_{3}$ treatment had a significant effect on germination in growth chamber $\left(+5^{\circ} \mathrm{C}\right)$ but there wasn't any difference between $\mathrm{GA}_{3}$ doses (Table 3). Smilarly, Pawlowski (2009) reported that breaking of dormancy was stimulated by gibberellic acid in Acer platanoides seeds. GA $\mathrm{G}_{3}$ treatments of Acer hyrcanum seeds shortened the cold stratification period and increased germination but did not eliminate the requirement of cold stratification of the seeds (Naseri et al. 2018). In this study, it was found out that $\mathrm{GA}_{3}$ treatment had a significant effect on germination in greenhouse conditions (Table 4), but this effect was a negative. These results indicate very clearly that $\mathrm{GA}_{3}$ treatment of Acer trautvetteri seeds especially stratified before sowing in greenhouse doesn't have a positive effect on germination. Therefore, $\mathrm{GA}_{3}$ application should not preffered in the greenhouse sowing of Acer trautvetteri seeds. The same result has been determined in Acer cappadocium seeds (Erdogan Genc and Ucler 2020). Similarly, Stejskalová et al. (2015) found out that gibberellic acid did not increase the germination percentage compared to stratified seeds in Acerpseudoplatanus. Furthermore, Webb and Wareing (1972) reported that $\mathrm{GA}_{3}$ treatments had no effect for breaking dormancy in Acer pseudoplatanus seeds. Whereas, Zare (2014) obtained the highest percentage of germination in Acer menspesolanum subsp. turcomanicum after $500 \mathrm{ppm}$ and $250 \mathrm{ppm}$ gibberellic acid treatments with five months moist chilling. Although growth chamber and green house results both indicated that seed collection time did not seem to play a role as statistically on seed germination, there was a significant interaction between seed collection time and stratification in greenhouse conditions (Table 4). The highest germination was obtained in seeds collected at third collection time and sown after 8 eight weeks cold stratification $(60,16 \%)$. In addition, when germination percentages were also evaluated in terms of treatments, the highest germination ( $81 \%)$ in the greenhouse was detected in the seeds collected at collection time 3. Also, there was a positive correlation between seed collection time and germination $(\mathrm{r}=0.59)$. As a result, the third collection time (in october) should be preferred as seed collection time in Acer trautvetteri seeds, considering that it may vary according to the climatic conditions of the year and different location on area of natural distribution of this species or population.

\section{ACKNOWLEDGEMENTS}

\section{ZAHVALA}

We would like to thank Karadeniz Technical University Scientific Research Projects Department (Project No:2005.113. 001.1.) for financial supporting. This study was a part of Hanife ERDOĞAN GENÇ Ph.D thesis.

\section{REFERENCES}

\section{LITERATURA}

- Ansin, R. and Ozkan, Z.C., 1997: Tohumlu Bitkiler (Spermatophyta), Odunsu Taksonlar, Karadeniz Teknik Üniversitesi, Orman Fakültesi Yayınları, p: 479-480, No:167/19, Trabzon.

- Beyhan, N., Marangoz, D. and Demir, T., 1999: The Effect of $\mathrm{GA}_{3}$ and Stratification on Hazelnut Seed Germination and Seedlings Grown with and without Plastic Tube, Ondokuzmayıs Üniversitesi, Ziraat Fakültesi Dergisi, 14, 3, p:54-64, Samsun, Turkey.

- Bourgoin, A. and Simpson, J.D., 2004: Soaking, Moist-chilling and Temperature Effects on Germination of Acer pensylvanicum Seeds, Canadian Journal Forest Research, 34,10, p:2181-2185.

- Bradbeer, J.W., 1988: Seed Dormancy and Germination, Botany King's College London, Blackie Press, p:151, Newyork, USA.

- Chauhan, K.C. and Arun, K., 1998: Significance of Diameter Classes and Picking Dates on Seed Physical and Germination Traits in Acer oblongum Wall., Van Vigyan, 36, 1, 1-7, Nauni.

- Chen, Shepley S.C., and Chang, Judy, L.L., 1972: Does Gibberellic Acid Stimulate Seed Germination via Amylase Synthesis?, Plant Physiol., Vol.49, 441-442 p.

- Davis, P.H., 1969: Flora of Turkey and the East Aegean Islands, Vol.II., Edinburg Universty Press, 578p., Edinburgh.

- Derkx, M.P.M., 2000: Pretreatment at Controlled Seed Moisture Content as an Effective Means to Break Dormancy in Tree Seeds, In: Viemont, J.D.( Editor), Dormancy in Plants: From Whole Plant Behaviour to Cellular control, CABI Publishing, USA, p:65-69.

- Drâghici, C., Abrudan, I.V., 2010: Dormancy Breaking of Acer and Fraxinus Seeds-a Brief Review, Bulletin of Transilvania University of Braşov, Vol.3 (52), p:29-32, Braşov.

- Erdogan Genc, H., Ucler, A.O., 2020: Effect of Different Treatments on Seed Dormancy Breaking and Germination in Acer cappadocicum Gleditsch var. cappadocicum, Šumarski List, 3-4, p:159-166

- Evans, E. and Blazich, F.A., 1999: Overcoming Seed Dormancy: Trees and Shrubs, Department of Horticulture Science, Horticulture İnformation Leaflets, NC State Unıversty, US (online) https://content.ces.ncsu.edu/overcoming-seed-dormancy-treesand-shrubs.

- Farhadi, M., Tigabu, M., Arian, A.G., Sharifani, M., Daneshvar, A., Oden, O.C., 2013: Pre-sowing treatment for Breaking Dormancy in Acer velutinum Boiss. Seed lots, Journal of Forestry Research, 24(2):273-278, Northeast Forestry University, Harbin, China.

- Farmer, R.E. and Cunningham, M., 1981: Seed Dormancy of Red Maple in East Tennesee, Society of American Foresters, For. Sci., 27, 3, 446-448.

- Genc, M., 2012: Süs Bitkisi Yetiştiriciliği, Süleyman Demirel Üniversitesi yayınları, Yayın No:55, s. 325, Isparta.

- Gleiser, G., Carmen Picher, M., Veintimilla , P., Martinez, J., Verdü, M., 2004: Seed Dormancy in Relation to Seed Storage Behaviour in Acer, Botanical Journal of the Linnean Society, Volume 145, Issue 2, June 2004, p:203-208.

- Gultekin, H., C., 2007: Akçaağaç (L.) Türlerimiz ve Fidan Üretim Teknikleri, Çevre ve Orman Bakanlığı Ağaçlandırma ve Erozyon Kontrolü Genel Müdürlüğü, Fidanlık ve Tohum İşleri Daire Başkanlığı Yayını, 24 s. Ankara.

- ISTA, 1996: İnternational Rules for Seed Testing, İnternational Seed Testing Association, Seed Science and Technology, Forest Service, US. 
- Jensen, M., 2001: Temperature Relations of Germination in Acer platanoides L. Seeds, Danish Institue of Agricultural Sciences, Scand.J.For.Res., 16, 404-414, Aarslev, Denmark.

- Korkut, S., Büyüksarı, U., 2006:Some Mechanical Properties of Red-bud Maple (Acer trautvetteri Medw.) Wood Grown in Different Districts, Duzce University, Journal of Forestry, 2(2):2431, Duzce-Turkey.

- Korkut, D.S., Guller, B., 2008: The Effects of Heat Treatment on Physical Properties and Surface Roughness of Red-bud Maple (Acer trautvetteri Medw.) Wood, Bioresource Technolgy 99, 2846-2851.

- Kumar, S., Shamet, G.S., Gupta, D., Kumari, N., Kumar, R. 2017: Effect of Stratification and Gibberellic Acid on Germination and Seedling Growth of Acer acuminatum in North Western Himalayas, Indian Forester,143 (11):1105-1111, India.

- Marković, M., Grbıć, M., Skočajıć, D., Đukıć, M., ĐunısijevıćBojović, D. 2019: Affect of Different Seed Treatments on Dormancy Breaking and Germination of Acer cappillipes Maxim, Conference: X International Scientific Agriculture Symposium “AGROSYM 2019", Jahorina (online) https://www.researchgate. net/publication/337593288.

- Naseri, B., Tabari, M., Phartyal, S.S., Abedi, M., 2018: Deep Physiological Dormancy in Seeds of Balkan maple (Acer hyrcanum): A Rare Tree in the Hyrcanian Mountain Forests, Seed Science and Technology, 46, 3, 473-482.

- Ognjenović, M., Čehulić, I., Kaliger, A., Križanec, M., Laslo A., Seletković, I., Potočić, N. 2018: The Influence of Soil Conditioner "Herbafertil" On The Growth and Development of Amur Maple (Acer tataricum L. ssp. ginnala Maxim.) In A Nursery Trial, Šumarski list, 7-8, p: 351-362.

- Ozdamar, K., 2010: Paket Programlar ile İstatistiksel Veri Analizi-I, 7. Baskı, Kaan Kitabevi, s:522, Eskişehir.

- Pawlowski, T.,A., 2009: Proteome Analysis of Norway maple (Acer platanoides L.) Seeds Dormancy Breaking and Germination: Influence of Abscisic and Giberellic Acid Seeds, Seed Science Research, 9, 48, Kornik, Poland.

- Peroni, P.A., 1995. Field and Laboratory İnvestigations of Seed Dormancy in Red maple (Acer rubrum L.) from the North Carolina, Forest Science, 41(2), 378-386., Deparment of Botany, Duke University, Durham, USA.

- Phartyal, S.S., Thapliyal, R.C.,Koedam, N., Sandrine G., 2002: Ex situ Conservation of Rare and Valuble Forest Tree Species Through Seed-Gene Bank, Current science, 83, 11, pp.13511357.

- Phartyal, S.S., Thapliyal, R.C., Nayal, J.S., Joshi G., 2003: Seed Dormancy in Himalayan maple (Acer caesium): Effect of Stratification and Phyto-Hormones, Seed Science and Technology, $31,1,1-11$.

- Pinfield, N.J., Stutchbury P.A., Bazaid, SA., 1987: Seed Dormancy in Acer: Is there A Common Mechanism for All Acer species and What Part is Played in it by Abscisic Acid, Physiologia Plantarum, 71, 365-371.

- Pinfield, N.J. and Stutchbury, P.A., 1990. Seed Dormancy in Acer: The Role of Testa- imposed and Embriyo Dormancy in Acer velutinum, Annals of Botany, 66, 2, 133-137.

- Piotto, B. and Noi, A.D., 2003: Seed Propagation of Mediterranean Trees and Shrubs, ADAPT- Agency for The Protection of The Environment and for Technical Services, p.15, Roma, Italy.
- Saatcioglu, F., 1971: Orman Ağacı Tohumları, Tohumun Tedariki, Saklanması, Çimlenme Fizyolojisi, Kalite Kontrolü ile Önemli Ağaç ve Ağaççık Türlerinin Tohum Bakımından Özellikleri, İ.Ü.Yayın No: 1649, O.F.Yayın No: 173, Sayfa:109, İstanbul.

- Savage, W.E., Bergervoet, J.H.V., Bıno, R.J., Clay, H.A. ve Groot, S.P.C., 1998: Nuclear Replication Activity During Seed Devolepment, Dormancy Breakage and Germination in Three Species: Norway Maple (Acer platanoides L.), Sycamore (Acer pseudoplatanus L.) and Cherry (Prunus avium L.), Horticulture Research International, Annnals of Botany, 81, 519-526, The Netherlands.

- Stejskalová, I., Kupka, I., Miltner, S., 2015: Effect of Gibberellic Acid on Germination Capacity and Emergence Rate of Sycamore maple (Acer pseudoplatanus L.) Seeds, Journal of Forest Science, 61, 205 (8):325-331, Prague, Czech Republic.

- Tremblay, M.F., Mauffette, Y., Bergeron, Y., 1996: Germination Responses of Nothern Red Maple (Acer rubrum) Populations, Society of American Foresters, Forest Science, 42, 2, 154-159.

- Tylkowski, T., 1995: Adaptation of Dormant Seeds to Sowing by Cyclically Repeated Soaking in Water, III. Sycamore maple, Acer pseudoplatanus L., Sylwan, 13, 7, 15-23, Kornik, Poland.

- Ucler, A.O., ve Turna, I., 2005: Tohum ve Fidanlık Tekniği, K.T.Ü. Orman Fakültesi Ders Notları, Yayın No:78, s:126, Trabzon.

- Ulker, O., Hiziroglu, S. 2018: Thermo Mechanical Processing of Cappadocian Maple (Acer c.), Pro Ligno (www.proligno.ro), Online ISSN:2069-7430, Vol:14, pp.13-20.

- Urgenc, S., 1998: Ağaçlandırma Tekniği, İ.Ü. Rektörlüğü Yayın No:3994, Orman Fak. Yayın No:441, s:600, İstanbul.

- Varbeva, L., Iliev, N., 2015: Seed Qualities and Seed Dormancy Breaking of Sycamore Maple (Acer pseudoplatanus L.) seed, Forestry Ideas, vol. 21, No 1 (49): 97-105.

- Webb, D.P. and Dumbroff, E.B., 1969: Factors Affecting the Stratification Process in Seeds of Acer saccharum, Canada Journal of Botany, 47, 1555-1563.

- Webb, D.P. and Wareing, P.F., 1972: Seed Dormancy in Acer: Endogenous Germination Inhibitors and Dormancy in Acer pseudoplatanus L., Planta, 104, 2, 115-125.

- Webb, D.P., 1974: Germination Control of Stratified Sugar maple seeds, For.Chron, 50, 112-13.

- Yahyaoglu, Z., Olmez Z., 2005: Tohum Teknolojisi ve Fidanlık Tekniği, Kafkas Üniversitesi, Yayın No:1, 142 s., Artvin.

- Yahyaoglu, Z., Olmez, Z., Eminagaoglu, O., Temel, F., Gokturk, A., 2006: Artvin-Çoruh Havzasında Doğal Olarak Yetişen Bazı Çalı ve Ağaççık Türlerinin Fidan Üretim Tekniğinin Araştırılması, TÜBİTAK, Tarım, Ormancılık ve Veterinerlik Araştırma Grubu, Proje No: Tovag-3234, Sayfa: 24-29, Artvin.

- Yang J. ve Lin, T., 1999: Seed Storage Behavior of Five Species of Acer, Taiwan Journal of Forest Science, 14 (4), p. 479-492.

- Yilmaz, M., 2007: Depth of Dormancy and Desiccation Tolerance in Acer trutvetteri Medv. Seeds, Turk. J. Agric. For., 31, 201 205, TUBİTAK, Turkey.

- Zare, A., 2014: A Study of Different Treatment Effect on Seed Germination Characteristics and Seedling Survival Montpellier Maple (Acer menspessolanum subsp. turcomanicum Rech. F.), Indian Journal of Fundamental and Applied Life Sciences, Vol.4 (4), p. 455-464.

- Zasada, J.C. and Strong, T.F., 2008: Acer L., Woody Plant Seed Manual (online) http:// www.nsl.fs.fed.us/ wpsm/ Acer. pdf. 


\section{SAŽETAK}

Vrsta Acer trautvetteri Medvedev geografski je rasprostranjen na Kavkazu i u Turskoj. Pridolazi na visinama od 400 do $2100 \mathrm{~m}$. U ovom radu raspravljamo o savladavanju dormantnosti i značajkama klijanja sjemena vrste Acer trautvetteri Medvedev, jedne od glavnih vrsta javora u istočnom crnomorskom području. U tu je svrhu godine 2008. prikupljano sjeme u tri navrata s razmakom od 15 dana. Kako bismo savladali dormantnost, primijenili smo nekoliko tretmana klijanja. Tretmani su uključivali (1) različito vrijeme sakupljanja sjemena, (2) namakanje u vodi, (3) hladno-vlažnu stratifikaciju i (4), primjenu $\mathrm{GA}_{3}$ (giberelinske kiseline). Tretirano sjeme klijalo je u komori rasta pri $5^{\circ} \mathrm{C}$ i u stakleničkim uvjetima. Ovom studijom utvrđeno je da sjeme vrste Acer trautvetteri pokazuje fiziološku dormantnost i da je za savladavanje dormantnosti potreban period stratifikacije. Najviši postotak klijavosti sjemena vrste Acer trautvetteri u komori rasta uz primjenu $\mathrm{GA}_{3}$ nakon osam tjedana stratifikacije iznosio je $66 \%$. Najviši postotak klijanja u stakleniku postignut je hladnom stratifikacijom nakon osam tjedana (81\%). Postotak klijanja sjemena vrste Acer trautvetteri stratificiranog tijekom osam tjedana bio je viši od postotka klijanja nestratificiranog sjemena i u komori rasta i u stakleničkim uvjetima. Ova činjenica potvrđuje da sjeme vrste Acer trautvetteri pokazuje fiziološku dormantnost i da je za savladavanje dormantnosti sjemena potreban period stratifikacije. Iako je tretman s $\mathrm{GA}_{3}$ imao pozitivan utjecaj na klijavost u komori rasta pri $+5{ }^{\circ} \mathrm{C}$, tretman $s \mathrm{GA}_{3}$ negativno je utjecao na klijanje u stakleničkim uvjetima. Namakanje nestratificiranog sjemena u vodi nije pokazalo neku značajniju razliku na klijavost sjemena. Postoji pozitivna korelacija između vremena prikupljanja sjemena i klijanja $(r=0.59)$. Shodno tome, preporučuje se treće vrijeme prikupljanja (u listopadu) sjemena vrste Acer trautvetteri. Točno vrijeme sakupljanja sjemena može varirati ovisno o klimatskim godišnjim uvjetima.

KLJUČNE RIJEČI: Acer trautvetteri; sjeme, dormantnost, stratifikacija, giberelinska kiselina. 